\title{
Die einde is hier!' Tekstuele strategie en historiese verstaan in die Judasbrief
}

S J Joubert

Departement Bybelkunde (Afd B)

Universiteit van Pretoria

\begin{abstract}
'The end is here!' Textual strategy and historical understanding in the Letter of Jude

After a brief discussion of the performative functions of persuasive discourse in general, the socio-historical context of the letter of Jude is constructed. This is followed by a literary analysis of the rhetorical strategies in the letter in order to persuade the intended readers to reject a group of teachers in their midst with conflicting perceptions of reality. In this regard, the author's transtextual reinterpretation and contextual application of well-known motifs, persons and groups from Jewish history, who all serve as types of divine intervention and punishment, receive particular attention. Jude applies the principles of identification and association to villify his opponents. By hermeneutically shifting the emphasis from his present context to the past, Jude, through various textual strategies, identifies the opponents with the notorious archetypes of sinners' from history who defined the nature of sin and disobedience to God. But, at the same time, the present 'chaos' caused by these teachers are also related to the final eschatological events in the divine calender.
\end{abstract}

\section{OORREDENDE DISKOERS}

Taal kan op verskillende maniere in diskoers georganiseer word, afhangende van die funksies wat dit binne verskillende kontekste vervul. Deskriptiewe diskoers, narratiewe diskoers en oorredende diskoers is maar enkele van die maniere waarop inligting binne

* Aan professor Johannes Engelbrecht, met groot genoeë. Dankie vir u kollegialiteit en vriendskap! 
kommunikatiewe situasies gestruktureer kan word. In hierdie artikel val die klem primêr op die argumentatiewe of oorredende funksies van taal soos wat dit neerslag vind in die Judasbrief.

'n Oorredende situasie veronderstel ten minste 'n orator, 'n gehoor en 'n subjek as die fokuspunt van die argument of gesprek (Perelman 1979:11). Die doel van hierdie tipe kommunikasie is om die gehoor/lesers te beweeg vanaf een ideologiese posisie of standpunt inname na 'n ander. Binne oorredende situasies gaan dit dus oor die aanwending van bepaalde strategieë aan die kant van die spreker/skrywer om die waardeoordele en, daarmee saam, die gepaardgaande gedragsresponse van die ontvangers binne 'n gegewe kommunikatiewe situasie te wysig of aan te pas. In die woorde van Austin (1962:6), een van die vaders van die taalhandelingsteorie, het oorredende diskoers ten doel '... to purposefully influence other persons' behaviour and beliefs'.

Die aard van die verlangde respons(e) aan die kant van die gehoor/lesers wissel uiteraard na gelang van die saak onder bespreking binne 'n gegewe situasie. Binne religieuse kontekste word daar byvoorbeeld meestal 'n sterk appél op die waardestelsels en die gedrag van die gehoor/lesers gemaak. Die spreker/skrywer bevind hom/haarself gewoonlik hier op die morele hoëgrond, met die gehoor/lesers as diegene wat nie alleen net oor ontoereikende kennisinhoude beskik nie, maar wat ook 'illegitieme' standpunte en gedragswyses aanhang wat as 'n bedreiding vir die voortbestaan van 'n gegewe simboliese universum dien. Die doel van sodanige oorredende diskoers is om gewoonlik dan aan die hand van verskillende retoriese strategieë die hoorders/lesers te beweeg '...to conform to the author's interpretation of the way things are' (Joubert 1995:76).

Enige vorm van oorreding is konteksgebonde (vgl Fowler 1986:88-89). Dit vind met ander woorde altyd plaas binne 'n bepaalde sosio-kulturele konteks en, in die geval van geskrewe literatuur, ook binne 'n bepaalde intratekstuele situasie. Oorredende kommunikasie moet daarom ten eerste verstaan word vanuit die breër netwerk van sosiale konvensies, waardes en instellings wat in die gegewe sosiale sisteem funksioneer waarbinne die spreker/skrywer en die hoorders/lesers hulle bevind. Hierdie gedeelde (implisiete en eksplisiete) kennis van 'n bepaalde sosiale sisteem tussen skrywer en lesers/spreker en hoorders, bepaal grootliks die aard en inhoude van die skrywer/ spreker se retoriese strategieë.

Tweedens, in die geval van skriftelike oorredende literatuur, moet die intratekstuele argumentatiewe situasie waarbinne die kommunikasie tussen die geënkodeerde outeur en lesers plaasvind ook deeglik in ag geneem word. Hier moet die rol van sowel die eksplisiete- en die implisiete outeur verdiskonteer word. Die implisiete ou- 
teur, as die organiserende prinsipe binne die teks, verleen nie net 'n bepaalde identiteit aan die eksplisiete outeur nie, maar hy/sy begelei die lesers ook deurgaans aan die hand van bepaalde strategieë hoe om die teks te verstaan. Die rol van sowel die eksplisiete as die implisiete lesers is uiteraard ook van belang (vgl ook Weaver 1990:41-42). Die funksies van die eksplisiete leser(s) en implisiete leser(s), wat aan die hand van verskillende tekstuele aanduiders 'n bepaalde beeld aanneem, dien as identifikasiemedium vir die beoogde (buitetekstuele) lesers. Indien die kommunikasieproses geslaagd wil wees, moet die reële lesers hulle eventueel identifiseer met die 'beeld' wat die teks van hulleself daarstel.

Uiteraard tree al die bovermelde intratekstuele persone binne 'n bepaalde 'tekswêreld' op. Hierdie wêreld, wat uit al die implisiete en eksplisiete semantiese komponente van die teks bestaan, stel 'n selfstandige (outo-semantiese) diskoers-situasie, of in die geval van oorredende tekste, 'n argumentatiewe situasie daar.

Oorredende literatuur, soos kortliks hier omskryf, vereis aan die een kant dus 'n grondige kennisname van die literêre aard van 'n bepaalde teks, maar aan die ander kant vereis dit ook kennis van die ontstaansituasie en resepsie van hierdie teks. Genoemde histories-pragmatiese funksies van enige oorredende teks moet in ag geneem word ten einde ' $n$ legitieme sosiale konteks vir die argumentatiewe situasies wat daarin gereflekteer word, te kan konstrueer.

\section{DIE JUDASBRIEF}

\subsection{Die sosiale konteks van Judas}

Die Judasbrief was vir 'n geruime tyd een van die stiefkinders binne navorsing op die terrein van die Nuwe Testament. Maar sedert die middel van die tagtigerjare het dit dramaties verander. 'n Hele aantal invloedryke kommentare op Judas het sedertdien die lig gesien, soos dié van Bauckham (1983); Frankemölle (1987), Paulsen (1992), Neyrey (1993) en Vögtle (1994). Hiermee saam het daar ook 'n hele aantal vakwetenskaplike artikels op die Judasbrief verskyn, sowel as 'n aantal belangwekkende monografieë soos dié van Bauckham (1990), Heiligenthal (1992) en Charles (1993).

Wat die sosio-historiese agtergrond van die Judasbrief betref, is die brief self ons vernaamste bron van inligting. Helaas is die gegewens wat hierin voorkom, baie kursories van aard, en boonop ook nog sterk gestempel deur die religieuse en retoriese perspektiewe van die outeur. Gegewe al hierdie probleme, sou ons hoogtens $n$ tentatiewe konstruksie van die situasie wat hierdie skrywe genoodsaak het, kon daarstel. 
Die outeur (van nou af word hy bloot as 'Judas' aangedui) reageer skerp op die teenwoordigheid van 'n aantal indringers in die kerk/ groep aan wie hy skryf. Hierdie mense staan volgens hom vyandig teenoor die apostoliese tradisie (vers 17-18). Hulle propageer hulle vreemde godsdienstige beskouinge tydens byeenkomste - veral tydens die $\dot{\alpha} \gamma \dot{\alpha} \pi \eta$ feeste - van sy groep (vers 12). Verder maak hierdie mense hulle ook aan bepaalde vorme van wangedrag skuldig. Dis egter nie so maklik om te bepaal (a) wat hulle verkondig het, en (b) watter tipe gedrag hulle nagevolg het nie. In lyn met tipiese vroeg-Christelike 'villifikasie-strategieë' (kyk bv Du Toit 1992:285-90) beeld Judas hulle doelbewus as skaduagtige incognito figure uit. Daarom bring hy hulle gedrag deurgaans in verband met 'n paar 'berugte sondige argetipes' vanuit die verlede (kyk bv afd 2.2.2.4) om sodoende 'n organies-historiese relasie tussen hulle en hierdie 'groot sondaars' daar te stel. Judas se doel is dus nie soseer om vir ons 'n inhoudelike beskrywing van die gedrag van sy opponente te gee nie, maar om hulle eerder te identifiseer met daardie sondaars uit die verre verlede wat nou onder God se straf gebuk gaan.

In die lig van die feit dat Judas sy opponente tog wel met bepaalde 'stereotipe' sondes uit die Joodse geskiedenis in verband bring, soos seksuele immoraliteit (vers 7 $8 ; 10$ ), opstand teen die gesag van die hemelwesens (vers 8-10) en ongehoorsaamheid aan die wet van God (vers 11 ), sou ons die vermoede kon waag dat ons hier met 'n sogenaamde anti-nominianistiese, charismatiese groep te make het. (In die teks word voortaan na hulle, vanuit Judas se perspektief, as 'vals leraars' en 'indringers' verwys.) Hierdie groep het hulle blykbaar daarop beroep dat hulle spesiale openbarings van die Gees in hulle drome ontvang (vers 8) wat hulle onthef het van enige verantwoordelikheid jeens die wet, die apostels en die hemelwesens. Ten spyte van Judas se strategie om so min as moontlik persoonlike opmerkings oor hulle te maak, blyk dit tog uit die styl en inhoud van die brief dat hierdie mense reeds ' $n$ groot deel (die grootste deel?) van die kerk aan wie hy skryf agter hulleself geskaar het.

\subsection{Judas se tekstuele strategie}

\subsubsection{Die inleiding en tema (vers 1-4)}

In die aanhef ( $v$ v 1-2), en in die daaropvolgende vermelding van die tema van die skrywe (vers 3-4), skep die eksplisiete outeur 'n intieme relasie tussen hom en sy eksplisiete lesers. Terselfdertyd baken hy ook hulle onderskeie rolle binne die intratekstuele gesprek duidelik af. Hy identifiseer homself in vers 1 as: 'Ioú $\delta \alpha \varsigma$ 'I $\eta \sigma o \hat{v}$

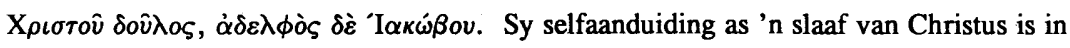
lyn met die geykte gebruik onder gesagsfigure binne die vroeë Christendom om by groetformules aan die begin van hul briewe hulle eie gesag te onderbeklemtoon en hulle 
groetformules aan die begin van hul briewe hulle eie gesag te onderbeklemtoon en hulle gehoorsaamheid aan Christus op die voorgrond te stel (vgl ook Fil 1:1; Tit 1:1; Jak 1:1; 2 Pet 1:1; Op 1:1). Die direk daaropvolgende frase, waar Judas se familieverbandskap met Jakobus vermeld word, stel sy eie gesag egter meer eksplisiet aan die orde. Hy noem slegs dat hy Jakobus se broer is, maar verswyg die feit dat hulle ook broers van Jesus is. Dit veronderstel dat die beoogde lesers met hierdie belangrike inligting op hoogte was.

Hierdie goed gekose bekendstelling van Judas onderstreep van die begin af dat hy die meeste gesag in die relasie tussen hom en die lesers besit. Daarom het hy die reg om onderwysend en, wanneer nodig, ook voorskriftelik teenoor hulle op te tree.

Die lesers word op 'n baie positiewe wyse as $\kappa \lambda \eta \tau o \hat{\imath}$ beskryf. Hulle bevind hul-


hulle word ook deur Christus bewaar (vers 1). Judas se hieropvolgende gebed in vers 2

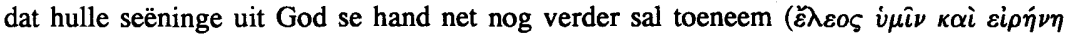
$\kappa \alpha i \dot{\alpha} \gamma \alpha \dot{\alpha} \pi \eta$ ), dra ook by tot die skepping van 'n baie suksesvolle capitatio benevolentiae (Joubert 1995:81). Die eksplisiete lesers se religieuse status as mense wat volledig deel het aan Christus se verlossing, is dus hierdeur bevestig. Vanselfsprekend het hulle daarom 'n legitieme plek binne die ware kerk wat in die apostoliese tradisie gegrondves is (vers 4).

Judas se positiewe verhouding met die lesers word in vers 3 en 4 nog verder uit-

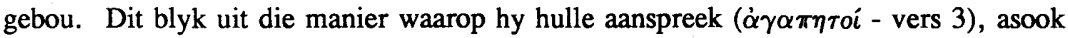

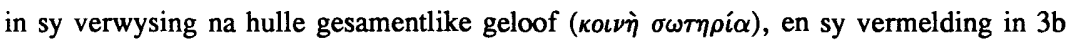
dat hulle almal ook deel het aan die geloof wat 'eens en vir altyd aan die heiliges oorgelewer is.' Uiteraard is hierdie laudatio in vers 1-3 baie belangrik, nie alleen net om 'n positiewe rapport tussen eksplisiete outeur en lesers daar te stel nie, maar ook om as ' $n$ identifikasiemedium vir die beoogde lesers te dien. Vanaf vers 5-19 verskaf Judas welliswaar ' $n$ ietwat ander beeld van die implisiete lesers aan ons. Aan die hand van verskillende tekstuele strategieë (kyk bv afd 2.2.2.4) toon hy op die dieptestruktuur van die teks aan dat die implisiete lesers eintlik nie so gelowig en so toegewyd is as wat hulle behoort te wees nie. Aangesien die eksplisiete lesers se identiteit as volwaardige Christenmense egter reeds hier in die inleiding bevestig is en dus bo verdenking staan, is die buitetekstuele lesers daarom deurgaans onder druk om nie met die implisiete lesers nie, maar wel met die eksplisiete lesers te identifiseer en hul gedrag dienooreenkomstig aan te pas.

In vers 4 verduidelik Judas hoekom hy sy lesers in vers 3 opgeroep het om die ware geloof te beskerm. Onmiddellik verander sy taal en toonaard as hy nou vertel hoedat sekere mense ( $\tau i \nu \varepsilon \varsigma \check{\alpha} \nu \theta \rho \omega \pi o$ ) die kerk binnegesluip het. In 'n neutedop sê Judas eintlik hier alles oor laasgenoemdes wat hy in vers 5-19 vanuit verskillende ander invalshoeke verder toelig: 
* Hierdie naamlose, incognito figure is goddeloos ( $\dot{\alpha} \sigma \varepsilon \beta \varepsilon i \varsigma)$;

* hulle misbruik die goedheid van God om aan te hou sondig ( $\dot{\alpha} \sigma \varepsilon \lambda \gamma \varepsilon \iota \alpha)$;

* hulle verloën vir God en vir Christus; en

* as gevolg van al hulle oortredings is hulle plek in God se oordeel klaar bespreek.

\subsubsection{Die indringers word ontmasker (vers 5-19)}

Judas maak ruimskoots gebruik van opsommings en aanhalings uit die $\mathrm{Ou}$ Testament en ander Joodse apokaliptiese werke om die negatiewe bepaalde beeld wat hy in vers 4 van sy opponente daargestel het verder te versterk. Sy ongekwalifiseerde gebruik van hierdie Joodse tekste en motiewe, en met name vanuit die apokaliptiese taal van die vroeë Judaisme(s), dui daarop dat sy beoogde lesers ook goed op hoogte hiermee was en waarskynlik vanuit hierdie kringe afkomstig was.

\subsubsection{Judas 5-7: Drie 'argetipes' van sonde uit Israel se geskiedenis}

In die eerste opsomming word drie voorbeelde van ongehoorsaamheid uit die Pentateug aangehaal, naamlik Israel se ongeloof in die woestyn, die engele wat nie binne hulle afgebakende plek in die hemel gebly het nie en seksuele gemeenskap met vroue op aarde gehad het, en Sodom en Gomorra (vgl Gen 6; 19; Num 14). Hierdie drie voorbeelde van goddeloosheid word dikwels binne vroeg-Joodse tekste aangehaal (vgl bv Jesus Sirag; 3 Makkabeërs, die Gemeenskapsdissipline Rol in Koemraan), en ook altyd in dieselfde volgorde as in die Pentateug (Neyrey 1993:59). Judas wyk egter van hierdie patroon af deur Israel se ongeloof in die woestyn eerste te vermeld. Hy doen dit waarskynlik om 'n tipe 'Steigerung' daar te stel in terme van God se straf. Vanaf vers 5-7 word sy oordeel telkens meer 'grafies' beskryf. Dit intensifiseer vanaf Israel se vernietiging (vers 5), na die engele se gevangeskap in kettings tot en met die oordeelsdag (vers 6), tot by die ewige vuur as straf vir Sodom en Gomorra (vers 7).

\subsubsection{Judas 8-10: Die hemelse orde word beledig}

In vers 8 wend Judas hierdie 'argetipes' van sonde en van God se gepaardgaande oordeel aan om die gedrag en leringe van sy opponente te interpreteer. Meer korrek gestel: Hy bring nou sy opponente (oủzoı!) se gedrag in lyn met dié van die 'galery' van sondaars uit die verre verlede ten einde 'n organiese verband tussen hulle daar te stel. Al hierdie voorbeelde maak dit duidelik dat sonde tot oordeel en tot die ewige verdoemenis lei. Daar is geen uitsondering nie! Daarom kan Judas se opponente niks anders as straf te wagte wees nie. 
In vers 9-10 (wat deur middel van die sleutelwoord $\beta \lambda \alpha \sigma \phi \eta \mu \varepsilon i \nu$, wat drie maal in vers 8-10 voorkom, 'n logiese verband met vers 8 vorm, wat op sy beurt weer met vers 5-7 skakel) word die disrespek van Judas se opponente vir die hemelwesens aangespreek deur 'n aanhaling uit die Testament van Moses (vgl Bauckham 1990:235-280). Vanuit die beskikbare fragmente in ander dokumente lyk dit asof Moses en Satan volgens die Testament van Moses in 'n dispuut betrokke was oor Moses se liggaam kort na sy dood op die berg Nebo. Satan sou gesê het dat Moses nie op 'n eerbare begrafnis geregtig was nie omdat hy vroeër 'n Egiptenaar doodgemaak het. In reaksie hierop het Migael hom met 'n aanhaling uit Sagaria 3:2 verdryf deur vir hom te sê: 'Mag die Here jou bestraf!'

Deur hierdie aanhaling maak Judas dit duidelik dat Migael nie vir homself die reg toegeëien het om die Satan self te bestraf nie. Hy het hom eerder op die gesag van die Here beroep om dit te doen. Hierdeur wys Judas dat God die enigste morele en juridiese gesag binne sy simboliese universum besit. Selfs die belangrikste engele weet en respekteer dit.

In lyn met vroeg-Joodse beskouings was Judas en sy gemeenskap waarskynlik ook van mening dat Moses die wet op Sinai deur die bemiddeling van die engele ontvang het, en dat engele ook as beskermers van die wet opgetree het. Enige belediging teen die engele of teen die wet sou daarom binne hierdie kringe as growwe disrespek jeens die hemelse hiërargie beskou word. Waarskynlik het die indringers binne Judas se groep hulle aan sodanige tipe oortreding skuldig gemaak. Dit is daarom glad nie vreemd dat Judas sy gesiglose opponente (ov̉ou - vers 8 en 10) in sowel vers 8 as in vers 10 as godslasteraars etiketeer nie- die sterkste moontlike vorm van disrespek jeens God. Sulke mense hoort glad nie binne sy wêreld tuis nie. Hulle lewe is in chaos. Hulle is so ontembaar soos wilde diere ( $\alpha \lambda o \gamma \alpha \zeta \hat{\varphi} \alpha)$.

\subsubsection{Judas 11: Nog drie 'argetipes' van sonde uit die verlede}

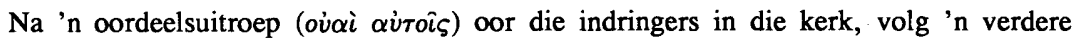
drietal voorbeelde van afvalligheid vanuit die Ou Testament, tesame met 'n reglynige toepassing daarvan op die vals leraars. Kain, die eerste moordenaar en die oertipe van alle sondaars, word ten aanvang vermeld. Daarna volg Bileam, die vals profeet wat Balak oorreed het om Israel tot afgodery te beweeg, en laastens Korag, die argetipe van almal wat teen die gesag van die wet in opstand is (vgl Neyrey.1993:73; Vögtle 1994:64-66). Judas kontekstualiseer dus nogmaals die normatiewe geskrifte van sy lesers om die opponente se 'ware aard' te onthul. Sy villifikasie-strategie is 'indirek' van aard. In plaas daarvan dat hy deurgaans in sy eie naam negatiewe uitsprake oor sy opponente maak, wend hy die gesaghebbende geskrifte van sy lesersgemeenskap in 
hierdie rol aan. Aan die hand van die dokumente wat sy gemeenskap as outentieke skriftelike gestaltes van God se woorde en dade beskou, kommunikeer Judas aan hulle dat die indringers lewensgevaarlike mense is wat 'n plek in die galery van die allerberugste sondaars uit die verlede verdien. Hulle name durf nie eens vermeld word sodat hulle 'n persoonlike identiteit kan aanneem nie.

\subsubsection{Judas 12-13: Voorbeelde van chaos uit die natuur tipeer die opponente}

In die enigste eksplisiete verwysing in die brief na die fisiese teenwoordigheid van die indringers binne die groep aan wie hy skryf, meld Judas in vers 12a dat hulle soos vuil kolle $(\sigma \pi \imath \lambda \dot{\alpha} \delta \varepsilon \varsigma)$ by die gemeenskaplike liefdesmaaltye uitstaan. Hulle is met anden woorde soos vullis wat nie hulle plek ken nie. Daarom besoedel hulle alles wat rein is. Met die hulp van 'n sestal metafore wat totale doodsheid en chaos in die natuur uitbeeld, word die onreinheid van hierdie indringers in vers 12-13 nog verder onderstreep. Hulle is onder andere soos wolke sonder water, soos bome sonder vrugte, soos onbeheerbare golwe in die see, en soos sterre wat koersloos uit hul baan in die hemelruim rondtrek en alles in hulle pad vernietig. Maar volgens Judas gaan God binnekort 'n einde aan hulle 'besoedeling' bring: Net soos met al die ander wie se name reeds in die 'galery van sondaars' verskyn (vers 5-7), gaan God hierdie indringers in die doderyk gooi - sy 'asblik' vir almal wat sy eer aantas. Daarom word daar nou al in die diep donkerte van die doderyk vir hulle 'n plek gereed gehou.

Dit is opvallend dat Judas geen eksplisiete uitsprake oor sy beoogde lesers se betrokkenheid by hierdie mense maak nie. Die feit dat hierdie vals leraars egter ongehinderd aan die agape-maaltye kon deelneem (vers 12a), wat kennelik die hartklop van hierdie groep se religieuse aktiwiteite uitgemaak het, veronderstel dat hulle ' $n$ groot aanhang moes gehad het. Die opmerking in vers 19 dat hulle verdeeldheid bring ( $\dot{\alpha} \pi \circ \delta \iota \rho i \zeta o \nu \tau \varepsilon \varsigma$ ), ondersteun hierdie vermoede. Judas se doelbewuste verswyging van sy lesers se betrokkenheid by hierdie mense aan die een kant, maar sy skerp veroordeling van die vals leraars aan die ander kant, skep op die oppervlaktestruktuur van die teks die indruk dat die eksplisiete lesers die onskuldige slagoffers van hierdie klomp boosaards is. Op die dieptestruktuur van die:teks sien dinge egter ietwat anders daar uit. Daar word 'n positiewe verwandskap tussen die implisiete lesers en die indringers wel gesuggereer. Die teksstrategie wat Judas deurgaans volg (bv sy aanduidings dat die 'ware geloof' in die gedrang is; volgehoue skerp kritiek op sy opponente; 'oordadige' aanwending van ander religieuse tekste; doelbewuste onderbeklemtoning van die lesers se betrokkenheid by die indringers; ens), kommunikeer tussen die lyne dat die lesers wel positief jeens sy opponente staan. Aangesien dit Judas se doel is om die beoogde lesers eventueel sover te kry om hulle heeltemal van hierdie mense te distansieer, gaan 
hy op die oppervlaktestruktuur baie versigtig met sy eksplisiete lesers om. Hy probeer dit so maklik as moontlik vir hulle maak om hulleself 'eerbaar' uit hierdie relasie los te wikkel (vgl Joubert 1995:84). Vandaar dan sy doelbewuste verswyging van enige betrokkenheid aan die kant van sy lesers by sy opponente.

\subsubsection{Judas 14-16: 1 Henog en die eindtyd}

In vers 14-15 haal Judas uit 1 Henog 1:9 aan waar gesê word dat die Here binnekort met sy engele terugkeer om oor die goddeloses te oordeel. Judas se gebruik van hierdie Joodse apokaliptiese werk, wat tussen die derde en die eerste eeu voor Christus ontstaan het, is natuurlik nie net beperk tot pasgenoemde aanhaling nie. Ook wat betref die metafore uit die natuur (Judas 12-13; 1 Henog $2: 1-5 ; 80: 2-8$ ); die sogenaamde 'mondsondes, soos godslastering en spoggery (Judas 4, 16; 1 Henog 67:9-10; 91:7), die verstaan van geloof (Judas 3, 20; 1 Henog 6:11, 46:3-8), ensovoorts, is daar duidelike raakvlakke tussen Judas en 1 Henog (vgl Heiligenthal 1992:64-89; kyk ook Heininger 1996:111-121). Judas en sy beoogde lesers het 1 Henog ongetwyfeld as 'n normatiewe geskrif beskou, dit wil sê as rigsnoer vir hulle religieuse denke en gedrag; vandaar sy ruimskootse aanwending van hierdie dokument.

Judas kontekstualiseer Henog se profesie deur die vals leraars as die direkte vervulling van die goddeloses te beskou. Hulle lei nou die 'laaste dae' hier op aarde in (vgl ook vers 18 ). Judas se opponente verkry sodoende 'n eskatologiese geladenheid as die sigbare vergestalting van dit wat die lesers se normatiewe geskrifte lank gelede berig het ten opsigte van die gebeure aan die einde van die tyd. Sodoende is hierdie persone veel meer as maar net 'n klompie goddeloses wat op pad is na die verdoemenis. Hulle is inderdaad die lewende bewyse dat die laaste fases van die geskiedenis sopas aangebreek het. Hulle optrede dui met ander woorde aan dat die einde op hande is!

Hierdie aanhaling uit Henog bring dus 'n nuwe aksent na vore. Waar die vorige aanhalings primêr ten doel gehad het om die opponente se 'status' as sondaars te bevestig wat onder God se cordeel gebuk gaan, verbind hierdie en ook die hieropvolgende aanhaling, hulle optrede aan die groot eskatologiese gebeure aan die einde van die tyd. Hulle is dus nie maar net deel van die berugte galery van sondaars uit die verlede nie. Nee, hulle hoort ook nog tot daardie spesiale kategorie van sondaars wat die eindtyd inlei. Dit het natuurlik belangrike implikasies vir die lesers. Dit sê vir hulle presies waar hulle hulle nou op God se kalender bevind. Hulle weet dat dit nou nie meer lank is voordat die groot kosmiese drama waarvan hulle ook deel, is sy hoogtepunt sal bereik nie. En hierdie wete plaas natuurlik nog meer druk op hulle om hulle van hierdie gevaarlike indringers te distansieer. 
Vers 16 is op die oog af ' $n$ losstaande vers wat fokus op die sogenaamde 'mondsondes' van Judas se opponente. Maar binne die opbou van die brief hoort dit logies by die profesie in vers 14-15. Nie alleen neem dit 'n verdere motief vanuit 1 Henog op nie, soos hierbo aangedui, maar dit volg ook dieselfde patroon as in vers 17-19. In hierdie verse tref ons 'n eskatologiese profesie van die apostels aan (vers 17-18), gevolg deur 'n praktiese toespitsing op Judas se opponente (vers 19). Ook vroeër in die brief kom hierdie oorhoofse patroon voor van 'n aanhaling uit een of ander normatiewe bron met 'n gepaardgaande toepassing daarvan op die indringers (vers 5-8; 9-10).

\subsubsection{Judas 17-19: Die apostels se profesie oor die laaste dae word waar}

Die laaste aanhaling om die goddelose aard van Judas se teenstanders te onderstreep, kom in vers 17-18 voor waar 'n mondelinge woord van die apostels aangetref word. Judas verleen profetiese status aan hulle woorde, soos wat sy gebruik van $\pi \rho \varepsilon \rho \eta \mu \varepsilon \dot{\varepsilon} \nu \omega \nu$ in vers 17 ook suggereer. As die stigters van die kerk aan wie al die hemelse misterieë toevertrou is, het hulle vroeër vir die lesers gewaarsku teen goddelose mense wat aan die einde van die tyd op die toneel sou verskyn. Volgens Judas het hierdie waarskuwing pas waar geword. God se groot plan met die wêreld het nou sy finale fases binnegegaan met die optrede van die dwaalleraars. Nou lê daar 'n tyd van swaarkry en volharding vir die kerk voor. Hulle swaarkry word vererger deur die feit dat hulle nou binne in die kerk met 'n klomp mense (ov̉oo!) te make het wat nie deur die Gees gelei word nie (vgl Paulsen 1992:77). Hierdie opmerking in vers 19 maak dit nogmaals duidelik dat die indringers nie tot die kring van die ware gelowiges hoort nie. Die belangrikste merkteken hiervan, te wete, die teenwoordigheid van die Gees, ontbreek in hulle lewe.

\subsubsection{Judas 20-23: Die gelowiges se verantwoordelikheid jeens ander binne hulle simboliese universum}

In vers 20 wissel die styl en toonaard dramaties wanneer die eksplisiete lesers weer direk aangespreek word. Laasgenoemdes se religieuse verantwoordelikheid jeens God, Christus en die Gees, die belangrikste Persone binne hul simboliese universum, word nou aan die orde gestel. Geen woord word egter gerep van die lesers se betrokkenheid by die leringe of aktiwiteite van die indringers nie. Net soos aan die begin van die brief, word hulle nou baie positief aangespreek. Judas versag byvoorbeeld sy voorskrifte aan hulle deur onder andere van partisipia met 'n imperatiewe strekking (vgl

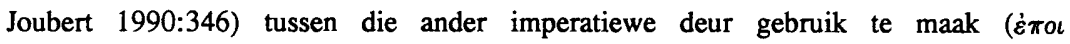

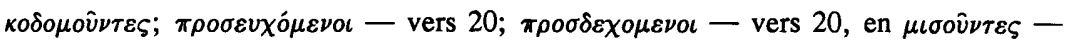


laaste dag voor God se oordeel moet gaan staan (vers 14-15), het die lesers niks te vrees nie. Hulle sal ongedeerd en met blydskap ( $\dot{\alpha} \mu \dot{\omega} \mu \nu_{\varsigma} \zeta \dot{\varepsilon} \nu \dot{\alpha} \gamma \alpha \lambda \lambda \iota \dot{\alpha} \sigma \varepsilon$ ) hulle plek voor Hom kom inneem. Daar bestaan nie meer die minste twyfel by Judas oor sy lesers se status nie. Hulle is op die regte pad. Vir hulle wag daar nie allerhande diep, donker plekke of swaar kettings in die doderyk soos wat met sy opponente die geval is nie. Die lesers gaan groot eer ontvang wanneer hulle binnekort voor Christus staan. Daarom kan hulle nou al saam met Judas juig en aan God en Christus eer toebring (vers 25).

\subsection{Evaluerende slotopmerkings}

Deur die loop van hierdie kort brief het Judas sy teenstanders se 'ware identiteit' duidelik aan die orde gestel. Hy het sy vyande as sondaars geëtiketteer deur hulle met die 'argetipes' van boosheid en van God se straf in die Joodse geskiedenis te identifiseer. Wanneer Judas ' $n$ bepaalde relasie tussen sy teenstanders en hierdie sondaars uit die verlede daarstel, moet ons laasgenoemdes egter nie as prototipes van die sondige gedrag van sy opponente verstaan nie. Ons het met ander woorde nie hier met 'n tradisionele tipologie-skema te make waar sekere ooreenkomste tussen bepaalde Ou-Testamentiese persone en gebeure, en persone en gebeure binne 'n gegewe Nuwe-Testamentiese konteks in terme van 'n 'Steigerung' of 'n eskalering van die ouere na die nuwere situasie uitgebeeld word nie. Nee, Judas gaan net mooi andersom te werk. Hy beweeg vanaf die hede na die verlede deur sy opponente met die berugte 'galery van sondaars' in verband te bring. Volgens Judas het hierdie mense in die verlede as 't ware die 'aard en inhoud' van opstand teen God gedefinieer en daaraan sigbare gestalte gegee. Hulle berugte reputasie en hulle uiteinde is algemene kennis. Net so het God ook baie duidelik deur die loop van die geskiedenis gewys hoe Hy teen sulke vorme van ongeloof en opstand optree. Deur dan nou sy opponente met hierdie argetipes in verband te bring, maak Judas dit duidelik dat presies dieselfde straf op hulle wag. Die kousale verband tussen sondige gedrag en die daaropvolgende straf is immers duidelik in die geskiedenis deur hom uitgewys, en funksioneer ook deurgaans as hermeneutiese prinsipe in die brief.

Bo en behalwe die nadruk op die kontinuiteit in God se handelinge deur die loop van die geskiedenis ten opsigte van straf en seën, wys Judas ook daarop dat die laaste fases van die geskiedenis met die optrede van die indringers aangebreek het. Hy ken verskillende tydperke in die geskiedenis. Daar is byvoorbeeld die 'tyd' van die engele (vers 6), die 'tyd' van Israel se tog deur die woestyn (vers 5), die 'tyd' van Henog (vers 14), die 'tyd' van Jesus Christus (vers 4), die 'tyd' van die apostels (vers 17), en die huidige 'tyd' van die vals predikers (vers $3-4 ; 16$ ). Uiteraard is tyd nie vir Judas 'n 
vers 21). Die eksplisiete lesers se status as kinders van God is ook glad nie in die gedrang nie. Al wat van hulle verwag word, is om hulle geloof nog sterker te maak (vers 20a); om te bid deur die Gees (20b); om in God se liefde te bly (21a) en om gelowig op die nuwe lewe te wag wat Christus skenk (21b).

Judas verskuif sy lesers se fokus in hierdie paranetiese gedeelte heeltemal weg van die situasie wat hy tot nou toe aangespreek het na God toe. Hulle verantwoordelikheid is om nou al die 'regte' godsdienstige dinge te doen sodat hulle in die regte verhouding tot die onsigbare Hoofde van hulle universum kan bly. Hulle hede moet gevul word met geloof, gebed en liefde. En hulle toekomsvisie moet bepaal word deur die verwagting dat hulle deel het aan die nuwe wêreld van God.

Nadat die lesers se religieuse verantwoordelikhede in vers 20-21 uitgespel is, kom hulle verantwoordelikheid jeens ander in vers 22-23 aan die orde. Judas se vae opmerkings dat hulle diegene wat twyfel, moet red en ander wat reeds in die sonde geval het, uit die vuur moet ruk, sinspeel kennelik op die situasie binne die groep aan wie hy skryf. Hy noem dat 'n paar mense (oîs) nog aan die twyfel is of hulle by die indringers moet inskakel of nie, terwyl 'n ander groepie (oùs) reeds by hulle aktiwiteite ingeskakel het. Beide hierdie groeperinge moet nou deur die lesers van die verkeerdheid van hulle optrede oortuig word. Hulle moet verhinder word om na die illegitieme universum van sy opponente te 'emigreer.' Judas waarsku sy lesers egter dat dit 'n baie riskante onderneming is, veral wanneer hulle met die tweede groepering te doen het wat eintlik al klaar 'in die vuur is' (23a). Hierdie mense kan hulle baie maklik kontamineer of besoedel (23b).

Judas wek die indruk dat die verdeeldheid in die kerk aan wie hy skryf (waarop hy ook in vers 19 gesinspeel het), glad nie so groot is nie. Dis slegs maar 'n paar gesiglose persone wat hierby betrokke is. Die eksplisiete lesers is egter op die regte pad. Daarom kan Judas hulle nou benoem tot 'beskermers van die ware geloof'. Hy doen dit omdat hy teen hierdie stadium van die intratekstuele gesprek daarvan oortuig is dat sy oorredende strategieë sy opponente genoegsaam ontmasker het om die beoogde lesers ook te oortuig om hulle die rug toe te keer. Die uiters positiewe beeld wat hier aan die eksplisiete lesers gekoppel word, plaas die buitetekstuele lesers natuurlik ook nou voor 'n voldonge feit: Of hulle identifiseer hiermee en bly binne die 'ware apostoliese simboliese universum,' of hulle word deel van 'die galery van die sondaars' wat onder God se straf gebuk gaan.

\subsubsection{Judas 24-25: Doksologie}

God se groot krag in die lewe van sy volgelinge word in die doksologie aan die orde gestel. Volgens Judas is Hy in staat om hulle te bewaar tot op die dag dat hulle voor Hom moet verskyn. Anders as in die geval van die indringers in die kerk wat op die 
abstrakte liniêre konsep nie. Nee, tyd word vir hom deur persone en gebeure bepaal, sodat ons hier van 'gebeuretyd' kan praat. Party van hierdie 'tydperke' oorvleuel natuurlik ook met mekaar, soos die tyd van Christus, wat God se groot Messiaanse era van redding ingelei het, wat oorvleuel met die tyd van die apostels en die vals leraars.

Volgens Judas het die tyd nou deur al sy voorafbestemde fases verloop en die einde bereik. Alles wat moes gebeur, het gebeur. Judas is dus in staat om die tyd te 'ontsyfer' deur duidelik vir sy lesers te wys hoe die indringers binne God se groot plan vir die wêreld inpas, en waar die lesers hulleself ook binne God se tydtafel bevind. Hulle kan nou self sien dat die einde nie meer ver is nie. Al wat nou vir hulle oorbly, is om vas te staan in hulle geloof en te wag op die laaste dag wanneer God se universele heerskappy sigbaar gemaak sal word (vgl ook die kenmerke van die vroeg-Christelike eskatologiese prediking in Klauck 1996:107-108). Op daardie dag sal al die oorblywende dele van God se groot plan soos die laaste stukkies van 'n legkaart in plek val. Dan sal die gemeenskap aan wie Judas skryf, ook deel in sy heerlikheid en sy triomf! Ten einde hieraan deel te hê, het hulle geen ander keuse as om hulle nou geheel en al van Judas se opponente te distansieer nie.

\section{Literatuurverwysings}

Austin, J L 1962. How to do things with words. Oxford: Oxford University Press.

Bauckham, R J 1983. Jude, 2 Peter. Texas: Word. 1990. Jude and the relatives of Jesus in the early church. Edinburgh: T \& $T$ Clark.

Charles, J D 1993. Literary strategy in the letter of Jude. Winona Lake: Eisenbruns.

Du Toit, A B 1992. Alienation and re-identification as pragmatic strategies in Galatians. Neotestamentica 26, 285-297.

Fowler, R 1986. Linguistic criticism. Oxford: Oxford University Press.

Frankemölle, H 1987. 1 und 2 Petrusbrief. Judasbrief. Würzburg: Echter.

Heiligenthal, R 1992. Zwischen Henoch und Paulus: Studien zum theologiegeschichtlichen Ort des Judasbriefes. Tübingen: Francke.

Heininger, B 1996. Paulus als Visionar: Eine religionsgeschichtliche Studie. Freiburg: Herder.

Joubert, S J 1990. Language, ideology and the social context of Jude. Neotestamentica 24, 335-349.

- 1995. Persuasion in the letter of Jude. JSNT 58, 75-87.

Klauck, H J 1996. Magie und Heidentum in der Apostelgeschichte des Lukas. Stuttgart: Verlag Katholisches Bibelwerk.

Neyrey, J H 1993. 2 Peter, Jude. New York: Doubleday. 
Paulsen, H 1992. Der zweite Petrusbrief und der Judasbrief. Göttingen: Vandenhoeck.

Perelman, C 1979. The new rhetoric and the humanities: Essays on rhetoric and its application. Dordrecht: Reidel.

Vögtle, A 1994. Der zweite brief des Petrus und der Judasbrief. Zürich: Neukirchener Verlag.

Weaver, D J 1990. Matthew's missionary discourse: A literary critical analysis. Sheffield: JSOT Press. 